DOI: $10.46640 / \mathrm{imr} .10 .19 .5$

UDK 2-81-154:638.252*Covid.191(497.6)

Pregledni članak

Review article

Primljeno: 8.2.2021.

\title{
Fahira Fejzić-Čengić
}

Fakultet političkih nauka, Sveučilište u Sarajevu, Bosna i Hercegovina

fahira.fejzic.cengic@gmail.com

\section{Medijsko praćenje ponašanja religijskih \\ hijerarhija u doba \\ epidemije}

\section{Sažetak}

Dok traje formalna socijalna izolacija svijeta i Sarajeva, dok se događa sve što se oko nas događa, live i uronjeno, religijske zajednice su također prisutne. Poput drugih gradova koje tri religije dodiruju i ispunjavaju, a to je najprije Jeruzalem, Sarajevo izranja kao europski original. Pratim istupe, nastupe, javna obraćanja ili vjerske corona poruke s tri vjerska izvorišta: islama, pravoslavlja i katoličanstva u ovom gradu. Koliko je sličnog, toliko je različitog, koliko je umirujućeg toliko je stresnog, koliko je korisnog toliko je štetnog. Šta će na kraju ili krajevima uslijediti? Tko zna? Ah nitko ne zna, krhko je znanje, reče naš sjajni pjesnik Antun Branko Šimić.

Ključne rïječi: pandemija, religïa, nadzor, homo sacer. 


\section{'Zar?!' - A uistinu oni nered sïu ali ne opažaju!}

('Ela innehum humul-mufsidun vela kin la ješurun'... (Sura Bekare, Krava, ajet 12, Kur’an))

U svom kratkom, ali znamenitom tekstu u cik pandemije covid19, talijanski je mislilac Giorgio Agamben 'Razmišljanja o kugi' konstatirao kako su moderna društva, ili ih možemo staviti i u jedninu, globalno moderno je društvo s lahkoćom prihvatilo osjećaj 'zaražnosti kugom', zatvaranje u kuće, ukidanje svog načina života, odbacivanje veza prijateljstva, ljubavi, rada, čak je napustilo svoja vjerska i politička ubjeđenja. ${ }^{29}$ Ovim jednostavnim zaključkom, autor nas uvodi u moćni zaključak kako je u stvari kuga, covid19, već postojala među nama, u nama, i kako je to stanje nepodnošljivosti dosadašnjeg načina života jedva čekalo da se (s) nečim izrazi, pojavi u javnoj sferi kako bi se sa svim starim stvarima i stilovima raskinuli prethodni odnosi.

Ono što nas u ovome tekstu i promišljanjima posebno zanima je pozicija religije, potrebe za religijom, kao i novosti koje su sa 'modernom kugom' nastupile u okrilju religije i religija u XXI stoljeću. Manje više sva ubjeđenja, uvjerenja, vjerovanja bilo koje vrste, a posebice religijska vjerovanja i pakse monoteističkih kao najbrojnijih religija naše epohe su izmijenjena, uvjetovana, pomjerena i pervertirana. U prvom talasu zatvaranja i ekstremnih slika i prikaza emitiranim na skoro svim masovnim medijima današnjice, prva religijska reakcija je bila jednako šokantna - ovo je apokalipsa. Ovo je taj kraj svijeta. Ili, ovo je taj početak kraja svijeta. O čemu evidentno govore sve velike religije i svi sveti spisi, islama, kršćanstva, judajstva. A da li je covid19 bio apokalipsa, već nakon nekoliko mjeseci ili godine dana možemo negativno odgovoriti - svijet i dalje, očito je, postoji.

Podsjetit ćemo da su u početku pandemije koja je počela u Wuhanu najprije Kinezi odustali od slavljenja svoje najznačajnije kulturno-religijske odrednice, Kineske nove godine, potom su hronološki padali i ostali najznačajniji praznici velikih religija, Uskrs i Vaskrs, oba su faktički u većinskim kršćanskim zemljama i društvima prošla neobilježeno. Barem ne na način kako se to događalo prethodnih stotina godina, ritualima u crkvama, manastirima i na okupljanjima sljedbenika. Papa je održao svoj čuveni govor Ubi et orbi na potpuno praznom vatikanskom trgu što je presedan kakav se ne pamti. Najradikalniji raskid sa uobičajenim ritualnim obrascima ipak su donijeli lideri islamskih zemalja, ponajprije predstavnici Saudijske Arabije gdje je srce obredoslovnog islama zaustavljeno. Tavvaf, kružno kretanje oko Kabe, Crnog kamena (Hadžerul -esveda) u Mekki je posve obustavljeno, a poznato je da se na ovakav način tavvaf nije zaustavio posljednjih hiljadu godina. Čak i kad brojne manje džamije i mesdžidi u ovoj zemlji profunkcioniraju, dvije.

29 Pogledati cio tekst http://www.buka.com/novosti/giorgio-agamben.razmišljanja.o.kugi, posjećeno 01. 09. 2020. 


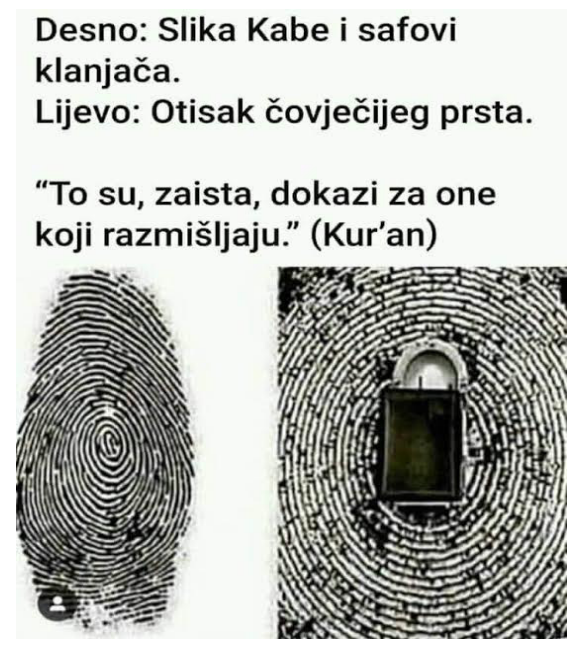

Ova je fotografija u 'dobu slike' postala vrlo dijeljena i upečatljiva i svojom je simboličlkom porukom upravo zbijala redove vjernika islama i snažila duhovnu dimenziju, da bi sa covidom19 potpuno nestala, i zamijenjena performansom nekoliko ljudi koji s kišobranima šetaju u bijelom okruženju 'svetog prostora'.

velike džamije, u MekkiiI Medini ostaju zatvorene za sljedbenike. ${ }^{30}$ Ova mala ilustracija koja uspoređuje papilarne linije ljudskoga prsta i kružne saffove oko Kabe u Mekki potvrđuje značaj prirodnog ili zgusnutog saffa Tavvafa, i ni jedan drugi oblik ga ne čini potpunim i cjelishodnim sem ovog prirodnog poretka ljudi koji obilaze svetinju u Mekki. Naknadne intervencije koje ćemo spomenuti samo ilustriraju nakaradan racionalni pristup organizacije Tavvafa u Mekki na način kontroliranog performansa sa vrlo malim brojem učesnika, potvrđujući tezu kako se vjerski lideri ni u svijetu nisu snašli, odnosno, nisu ni pokušali snaći, već su naprosto prihvatili naređenja ili komande iz Svjetske zdravstvene organizacije o tome kako da reorganiziraju Tavvaf. Simbolički, papilarne unikatne linije na svakom ljudskom prstu povezuju čovjeka sa kosmičkim silnicama koje zrače i isijavaju svoju osobitu energiju iz Crnoga kamena i iz stopljenih uokruženih ljudskih tijela koja u trudu, u odricanju, u znoju i posebnoj želji obilaze kružno i svjedoče da su usklađeni sa svim kružnim obrtanjima i jecajima kojima odzvanja ovaj naš veličanstveni svemir, kosmos, vasiona, kako god ga nazivali svojim malim ljudskim sitnim jezičkim mogućnostima.

$30 \mathrm{U}$ BiH džamije su uvele restrikcije pet dnevnih molitvi, namaza tako što je kolektivni čin, džematski namaz klanjan samo sa imamom, mujezinom I pet članova džamijskog odbora, jer svaka džamija ima takvo mini tijelo održavanja I brige o objektu džamije. Potom su polijepljene oznake duž cijele džamije sa dodatnom strelicom na svako pojedinačno mjesto gdje vjernik klanjač može sjesti ili stati. Otprilike kao jedan igrokaz sa obilježenim mjestima, što je sa stajališta obrednog saffa, tog obligatornog obrasca zajedničke molitve nedopušteno. Naime, razmaci ili rupe među klanjačima se smatraju grijehom, greškom, nedopuštenom stvari. Stoga je interes džematlija za kolektivni namaz uistinu smanjen, gotovo dokinut, bez obzira što se pandemijska krivulja mijenjala. Pravilo još uvijek važi. A religijske hijerarhije očito ne mare za klasične obligacije, saff mora biti popunjen, jer u prazninama stanuje šejtan, đavo, evil, iblis, sotona... prema vjerodostojnoj predaji Poslanika islma... 


\section{Viši svijet je spuštan na najniže stupnjeve, u blato i prašinu dnevnosti}

Agamben bi kazao kako se religijske zajednice ovoga trenutka ne umiju nositi sa novim izazovima svoje sljedbe i sa ljudskom potrebom za vjerovanjem u viši duhovni svijet. Stoga je, veli Agamben, to mjesto vjerovanja zauzela moderna nauka koju on sa razlogom naziva religijom modernog čovjeka. Zaključuje kako 'nauka kao i svaka religija proizvodi praznovjerice i strah, ili se bar može koristiti za njihovo širenje...nikada nismo prisustvovali ovakvom spektaklu'. ${ }^{31}$ Ali ovaj spektakl koji u medijima pratimo, prateći religijske nastupe, religijske vođe i njihove poruke, konstatiramo zajedno sa Agambenom da se upravo nauka o covidu19 saplice u iste obrasce spektakla kakvi su tipični za religije u doba krize, kada se naočigled svih sudaraju sukobljena mišljenja i sukobljene preporuke, počev od toga da se od strane jednih poriče ozbiljnost zaraze, do onih koji u covidu19 vide čistu ortodoksiju koja se sama sobom potvrđuje, ali sva rješenja koja se nude prosječnom konzumentu medijskih prezentacija je - čista podjela. Ili, ili...

Sa svoje strane bih dodala da je sama pandemija sa popratnom infodemijom, pokazala najnoviju naučnu ili čak pseudonaučnu religiju, naime sam covid19 sa Svjetskom zdravstvenom organizacijom kao neobjavljenim božanstvom je postao je nova religija. Temeljna postavka ove nove religije je obavezno je vjerovati u covid19. Ko ne vjeruje, ne pripada nama i mi ćemo se s njim obračunati kao s herezom. Potom, jedna od važnih izvanjskih obilježja nove religije, kako sve religije imaju ta simbolična spoljna obilježja, ovdje je zaštitna maska na licu najbitnija. Ko nosi masku on je naš i sluša novu religijsku zapovijest, ko nije s maskom na licu on je očiti heretik i njega treba izolirati, izopćiti i na svaki način kazniti. Ekstremne kazne već su brojni medijski sadržaji upratili, od upada u kuće, materijalnih kažnjavanja do kazni zatvaranjima u prave zatvore jer se pravila nove covid19 religije ne poštuju. Ni jednog trenutka nije individualizirana covid religija, na primjer, izuzeci od maske su za astmatičare, za djecu, za alergičare, za bolesnike kožnih obilježja, ili za one koji su preležali zarazu...Ne, upravo kao u svakoj neslobodnoj, nadzornoj religiji, i ovdje sve mora biti isto za sve, i bez izuzetka.Treće ekstremno pravilo nove religije je odmakni se od svakog čovjeka. Svakako što više to bolje. Upravo suprotno svim uobičajenim religijskim motivima i zapovijestima, o bliskosti bližnjega svoga, o ljubavi među ljudima i unutar zajednice, ova nova religija propovijeda samoću, udaljenost, izolaciju i utihlost. Po mogućnosti jedna totalna izolacija koja što duže traje to vas više štiti od zaraze, i to ne treba ni propitivati, ni sumnjati u taj stav, niti se ikako tome opirati. Izuzetak čini medicinsko, posebno osposobljeno osoblje, koje je opremljeno svim mogućim zaštitama, od glave do pete, sa maskama, skafanderima, vizirima, rukavicama, specijalnom obućom...I to osoblje brine ne po Hipokratovoj zakletvi, pomoć svakome u svakoj prilici bez obzira na sve, već upravo suprotno, hijerarhijski - pomoć samo nekima, biranima, izdvojenima, privilegiranima. Javnost je čak tako dobro pripremljena na ove šokantne stavove, da su bili skoro neprimijetni bilo kakvi izgovori, prigovori ili posebna ljudska humana ponašanja koja su i dalje slavila ljudski život, pomoć bolesnome u nevolji ili zakletvu profesije etičkog ljekara ili medicinara.... ${ }^{32}$

31 Pogledati šire u tekstu https://www.buka.com/novosti/giorgio-agamben-razmišljanja-o-kugi

32 U ovo vrijeme pojavio se klip koji nas je sve podsjetio na otvaranje Londonskih olimpijskih igara 2012. godine sa uvi- 


\section{Homo sacer suuda i stalno oko nas}

Najzačudnije od svega, vezano za ovu temu je pojava da je u gotovo tromjesečnom intervalu došlo do sloma svih uvjerenja i zajedničkih ubjeđenja što smo ih kao građani Planete zemlje posjedovali. Ispalo je kao da ljudi više ni u šta drugo ne vjeruju, vjeruju samo u covid19 i golu, baš golu egzistenciju. I to onu najnižeg tipa, biološku egzistenciju i samo je ona bitna, nju se mora sačuvati pošto poto i jedino je važan ponovo onaj sjajni termin Giorgia Agambena homo sacer. Homo sacer je paradigma otuđenog, ogoljenog, obespredmećenog čovjeka, koji jedino vrijedi kao zbir svojih pojedinačnih organa, od njeg se može uzeti srce, krv, bubrezi, zglobovi, koljena...čija prodaja i cijene na tržištu posebnih nekretnina u ovo doba skaču do neslućenih granica. Nije iznenađujuće ako ovo sve nije pripremna faza za ustanovljenje jedne nove religije, nebožanske religije koja će izrastati na razvalinama oslabljenih božanskih zasada koristeći se tim elementarnim resursima iz unutrašnjosti čovjeka. O tome uostalom na više mjesta govore izvorni tekstovi brojnih navjestitelja počev od Adama, Noe, Mojsija, Isusa do Muhameda. (Adema as., Nuha as., Musaa as., Isa as., Muhameda as.) Nova intervencija pod kožu, kako su je ranije imenovali neki autori ima za cilj dodatno raspakirati božanski original ljudske nutrine pomoću vjerovatno nanotehnoloških inputa, kako bi se teror kontrole svake osobe uistinu ostvario kao nekad ispisivanim orvelijanskim, hakslijevskim ili pak kamijevskim metodama perverzije...'Homo sacer je onaj spram kojega su svi ljudi potencijalni suvereni', kazao bi Agamben. ${ }^{33}$

Tako uplovljujemo u doba koje je svedivo na golu egzistenciju i strah od njena gubitka i takvo jedno totalitarno društvo, jedna takva kultura i jedna takva civilizacija ne zaslužuju ništa drugo sem da uplove u luku tiranije kakvu evo veću skromnijim oblicima svjedočimo. ${ }^{34}$ Sve baš sve je u rukama online mogula današnjice. Pred nama je postmoderni Levijatan isukao svoje nano-sablje i nano-mačete, ne mareći za moral, etiku i duhovnost, Istinu, Dobrotu, Ljepotu, ne mareći za religiju Pravoga Tvorca sveg postojećeg, Boga dakle već upravo suprotno - Njemu usprotiv! - ulazeći u

dom u sličnu paradigmu na sceni otvaranja, gdje dominira ekstremno lječilište, kreveti, bolnice, medicisnko osoblje, I premijer Johnson koji se osobno tamo liječi...U realnosti, nakon 12 godina ovaj će ponovni britanski premijer fakat biti zaražen covid19 I biti hospitaliziran, dakako izliječen, pa je nemalo teško povjerovati da je sve samo skup koincidentnih detalja i mašte kreatora otvaranja ovih olimpijskih igara, koje su de facto najavile novi vrli svijet u eksplicitnom smislu te riječi...

33 Pogledati šire u knjizi 'Homo Sacer' istoga autora, na stranicama 77 i dalje u potpoglavlju Sveti život, 'Homo sacer', Suverena moć i goli život, Zagreb 2006. godine, Izdavač Multimedijalni institut, Zagreb. Ova eksplikacija zaslužuje citiranje: '1929. godine Elias Bickelman u članku o Rimskoj kraljevskoj apoteozi je eksolkicitno povezao paganski ceremonijal, funus imaginarium, s pogrebnim obredima engleskih i francuskih kraljeva...tu je jedna specifična aporijua. Svaki je čovjek sahranjen jednom, kao što samo jednom umire. U doba Antonina posvećeni je car bio spaljen dva puta; prvi put corpore drugi in effigie... Truplo je spaljeno na svečan i službeni način dok su mu ostaci pohranjeni u mauzoleju...A za pogreb Antonina Pija svečana korota počinje tek nakon pokopa kostiju i povorka počinje kad tijelo već leži u zemlji. Funus poublicum tiče se voštane lutke koja ima lice pokopanog...Prema tom se licu odnose kao da je stvarno lice umrlog. Lutka je sedam dana na dvoru liječena i tretirana kao živa...Za razumijevanje cijelog rituala odlučujuća je upravo priroda i funkcija slike...'

34 U prva četiri mjeseca pandemije najbogatiji ljudi današnjice su uvećali svoja bogatstva. Vrijedi navesti te impozantne cifre: Jeff Bezos kao osnivač Amazona je zaradio 34.6 milijardi dolara, osnivač Facebooka Mark Zuckerberg je zaradio 25 milijardi dolara, Bill Gates I Elon Musk su zaradili po 36 milijardi dolara. Pogledati na stranici: http://buka.com/ novosti/procurili-prvi-podaci-ko-se-najviše-obogatio-tokom-pandemij-bogatasi-zaradili.434 milijarde, pristupljeno, 30. 08. 2020. 
obezljuđeni i obezboženi novi vrli svijet u kojemu stoga sa razlogom možemo konstatirati vlastiti poraz, svako ponaosob, posebice tzv. religijski lideri i predvodnici koji ove procese ne uviđaju, na razumiju i ne misle.

\section{Neroni iz XXI stoljeća na pomolu}

Živimo doba očaja. To je sinonim za uvećani nadzor. Novi nadzor uvlači nam se pod kožu, i otkriva ne samo šta radimo već i šta mislimo $i$ šta osjećamo. Počelo je kao fokus na bolest, zarazu, kugu kako Agemben voli kazati, ali ako već sad na svakom ulazu u zgradu ili avion, prevoz ili državu mjerimo temperaturu, puls, pritisak, kakve se iz ovoga mogu izvući ekstremne implikacije, nije teško zaključiti. Njih je naime, uvijek važno prepoznati prije nego dospiju kao ostvarenja do nas.

Mi ljudi današnjice, nalikujemo na Nerone XXI vijeka, nismo kadri spoznati kako to izgleda kada zapalimo i kada stvarno gori Rim, već svi kao da moramo zapaliti Rim da bismo shvatili da smo pretjerali i da kad je već zapaljen nema spasa Rimu. Ta forma ljudskog egzistencijalnog pragmatizma od kojeg boluju čak i religijske hijerarhije a trebale bi da su od toga posve lišene, jeste mentalno predsoblje koje će omogućiti prekretnicu za nadzor ljudi. Yuvai Noah Harari,, izraelski historičar i analitičar piše kako nas baš ova potkožna nadzornost uvodi do 'uspostavljanja novih totalitarnih režima, gorih od svih koje smo ranije vidjeli. Mogu rezultirati ogromnim revolucijama na tržištima rada, u ekonomiji i ličnim odnosima. ${ }^{35}$ I dok djelomično gori Pariz, nije teško zaključiti da će doći na red i Berlin, i London i Rim i redom gradovi u kojima poniženi, osiromašeni ljudi pate...Ako se poveća nadzor nad građanima, mora se to uvijek balansirati sa nadzorom nad vladama i korporacijama, nastavlja autor Harari. Svi oni donose iznimno važne odluke, i dijele stotine milijardi dolara kako žele, a to je često presudno kamo vodi. Građanima je bitno da zaštite svoju privatnost, i da svako njihovo pojedinačno praćenje prati i vlade koje se time bave. U suprotnome, vanredne totalitarne mjere neće prestati i orvelijanski koncept neslobode je sinonim za našu budućnost, svejedno je, živjeli u Africi ili u Evropi...

Jer sve trenutačne mjere su u stvari dugoročne. Kaba je i dalje paradigmatična, ni nakon obreda hadža koji je bio više smiješan i posve nadziran nego svet i osebujan, tavvaf se nije vratio prvotnom obliku prisnosti i izvornosti makar da je situacija u državi posve stabilnija. Riječ je očito o nečemu drugome. Papa više ne izlazi na Vatikanski trg, naredni mali i veliki kršćanski blagdani su manje više ignorirali epidemiološke mjere. No, papa u njima nije učestvovao. Kako bi kazao filozof Alić, religijske kao i ine hijerarhije imaju svoje tajne, a 'tajna hijerarhijske tajne je baš u tome da se jedno govori a drugo čini, tako da je oko nas nastalo društvo u kojemu ljudi čak iako znaju i vide šta je istina a šta laž prihvaćaju stvari onako kako se od njih traži da vide, misle, oblikuju, jer svakoj hijerarhiji trebaju smjerni ljudi' ${ }^{36}$

$35 \mathrm{http}$ //corona-virus-prekretnica-za nadzor ljudi, pristupljeno, 2.09.20

36 Pogledati šire u knjigi Seada Alića 'Masovna proizvodnja narcizma', Zagreb, 2019., Sveučilište Sjever I CFM Zagreb, naa stranici 15 I dalje... 


\section{Tri stupnja religije: objektivni, subjektivni, duhovni}

Religijske elite Bosne i ostatka svijeta pokazale su se u svojoj krajnje racionaliziranoj religijskoj ali u biti antivjerskoj dimenzịi svoga imidža. Naime, krajnji pozitivizam sociologije, prava, bogoštovlja, ili akide usmjerile su kolektivni religijski život, forme, obrasce u doba covid19 kao posve prilagodljiv, rastezljiv i adaptirajući oblik. Time je zadovoljena samo prva stepenica razvoja religijskog u čovjeku. I to onaj tzv. objektivni stupanj religijskog života koji živi kao religijski život naroda, kolektiva, oni brojni smjerni ljudi, ali ne i onaj subjektivni stupanj religijskog života kao moj lični, osobni i duševni stupanj na kojemu hijerarhije ne postoje, pogotovo ne onaj treći, duhovni kao najviši stupanj religïskog života na kojemu su prevladani svi dualiteti i materijalni tragovi i gdje vlada potpuna harmonija čiste duhovnosti. Dakle, religija za osrednjeg čovjeka, kako ga naziva Nikolaj Berđajev, je ova vrsta religije koju je uškopljavao i trenirao covid19. 'Tu spadaju i desni i lijevi, tom 'demokratskom' tipu čovjeka. I monarhije i socijalističke republike jednako su potrebne masama, jednako su prilagođene osrednjem čovjeku'. ${ }^{37}$ I bit religije u ovom domenu je kako religijskih tako i državnih, obrazovnih, turističkih, akademskih institucija ostao jednak - takav da bi se lakše osrednjim čovjekom upravljalo. Ovaj put i da bi državne i korporativne institucije dodatno upravljale religijskim institucijama. Tako su djelovanja religijskih vođa, lidera, predstavnika hijerarhija u ovom periodu uistinu posve bila racionalizirana, nevjerska, nereligijska i naročito ne produ/hovljena. I na ovakovrsnim skupovima mi se kao naučnici obično bavimo prilično površnim i odraznim refleksijama i znanjima, teško nam je priznati kako uistinu stvarno malo o svijetu znamo, lakše ponavljamo i citiramo jedni druge u komunikativnoj zajednici istraživača. Naprosto nam je svima tako lakše. Da li mi uistinu znamo što je metafizika? Što je temeljna duhovnost? Kad se i kako se naša civilizacija primiče kraju? Je li to nešto jako blizu, ili ne? A to su istinski vjerski, duhovni i religijski vođe bili dužni iskazati u ova pandemijska vremena.

Urlich Beck bi u minucioznoj analizi modernosti konstatirao kako su rješenja za sve naše krize već $u$ odbačenim izvjesnostima prethodnih epoha.$^{38} \mathrm{~A}$ mi smo tako olahko odbacili šest epoha postojanja i obreli su u ovoj materijalnoj kao ponajmanje važnoj. Iz nje sudimo i djelujemo sa bezbrojnim

37 Vidjeti šire u knjizi Nikolaj Berđajev, 'Filozofija slobodnog duha', Izdavač Dereta, Beograd, $2007 .$, strana 27.

38 Beck kaže da je kriza moderne nesopćiva za deset hiljada godina. Gradi ovu misao na jednom primjeru kada je Kongres SAD imenovao komisiju koja bi generacijama koje dolaze nakon više hiljada godina pokazale na kojim se mjestima nalaze ležišta nuklearnog otpada koji je za njih smrtonosan. Članovi ove komisije su proučavali poruke Stounhedža od prije 1500 godina pne, izučavali piramide, Homera, Bibliju kako bi imali uvida u koju hiljadu godina nekoć...Htjeli su da deponije nuklearnog otpada obilježe sa oznakom mrtvačka glava. Ali su potom članovi ove komisije zaključili kako su trogodišnjaci različito reagirali na simbol mrtvačke glave. Ako je stajao normalno, preplašili su se, ako je pak stajao vertikalno uzvikivali su ' Jupi, gusari...Dakle, Beck će konstatirati da je kriza moderne nesaopćiva za deset hiljada godina...

Naspram ovog nesaopćivog proteže se vrlo saopćivi narativ vjerskog tipa koji kaže: Božanski zakoni popravljaju stanje ljudske zajednice. Zato što je sedam stanica kojima kao ljudi putujemo: Prva je čuveni dijalog dok smo bili samo nevidljiva duša-tvar u rukama Božjim I kad mu se kolektivno zavjetujemo na pitanje: 'Jesam li ja vas Gospodar? Sve glasno odgovore: Jesi, svjedočimo!; Druga stanica je majčina maternica, Treća stanica je ovaj materijalni svijet, Četvrta stanica je Međusvijet ili Berzeh na koji odlazimo po maloj I velikoj smrti, Peta stanica je proživljenje na otvorenom I povratak na početak, Šesta stanica je raj ili pakao I Sedma stanica je neposredna blizina kao duhovno posvjedočenje istine u Potpunoj Istini. Tek u toj ogromnoj protežnosti moguće je sagledati smislove I zaloge Postojanja. No, I to samo rijetkima pođe za rukom. Svima nam jako nedostaje široko, sveobuhvatno I slojevito znanje. 
greškama koje su često nepopravljive. Jer, svuda gdje uspostavimo neki sociološki aksiom, tu je u stvari golema rana. Bog je nauci trebao da bi ga nekoć naučnim metodama domišljala samoga Boga. Od sociologije do fikha ${ }^{39}$, akaida ${ }^{40}$, katehezisa ${ }^{41}$. Tako je racionalni čovjek zavolio racionalnog Boga. Jer, moderni čovjek naprosto ne smije priznati da sve što je moderna bez Boga proizvela rastače se u vazduh. ${ }^{42}$ Potreban nam je ungrund kao novi kanal poruke. Ungrund je vrsta osobne tajne. Dokaz da pojam nije kraj umovanja, i gdje mu se primičemo iz negativnog smjera. Božansko je nebiće, Nadbiće dakle. Ungrund je prostor tajne, onaj bezdan koji svjedoči božanski kao neizrecivi život. Zato je duhovni svijet nesalomljiv i neizreciv, neuništiv i vječan, vazda živ i nudi se svakome ko se pročisti i poželi. Original nad originalima. Samo se on u doba pandemija prikriva, sakriva i bježi od najezde svekolikog Zla.

Moglo bi se predmnijevati kako nova tehnologijska vlast ili tehnopol postmoderne želi se dokopati ungrunda, na svoj utilitararno inteligentan i osebujan način. Nesvjestan da je to u biti nemoguće. Svaka bi vlast to najviše voljela nadzirati. Homo sacera kao predmet promatrati, upotrebljavati i ismijavati. Svojim cinizmom, lucidnošću, inteligencijom zla i totalitarnom nakanom. Za potencijalnu 'propast normalnog svijeta' dostatna su dva zapadna i jedno istočno postignuće u čitanjima većine autora, egoizam kao individualizam, atomska bomba i odnosno demografska bomba. U pritajenom strahu, moderna je stvorila svijet samouništenja čovječanstva ali to ne želi priznati. Stoga su joj tendencije antimoderne stalno za vratom. Nadovezujući se na Becka koji potvrđuje da rizik jest društveni fenomen snažno podržan globalizacijom ali da ne bi mogao biti shvaćen niti percipiran bez uloge medija, očito je vrlo važno shvatiti da su svi ovi tokovi bili izrazito medijatizirani, medijski popraćeni i upućuju na značaj interdiskurzivnosti koju je neophodno cjelovitije sagledati u svrhu potpunog razumijevanja nadolazećih rizika i komunikacijskih implikacija na sve segmente života, pa i religijski.

\section{Božanski svijet, antropomorfni svijet, virtualni svijet...}

Sa intenzivnom globalizacijom se profilrala integralna stvarnost kao virtualija. Kao zamjena za živi realni svijet, božanski i početni original. U njemu je smrt još uvijek neizliječena rana i trajna bol kao najveća tragedija koja nas iskušava. Kako umrijeti? Kako nestati? A da ne boli?

Ako je nestala transcendencija, Bog slomljen treba uništiti i njegov prirodni svijet i zamijeniti ga umjetnim od raznih dijelova zbog kojega se nikome ne podnosi račun. Tehničko virtualno se javlja kao konačno rješenje u toj nemogućoj razmjeni svijeta. ${ }^{43}$

39 Znanje o pravnim normativima u islamskim naukama

40 Znanje o biti vjerovanja I božanskoga djelovanja u islamskim naukama

41 Osnovna dogmatska znanja u kršćanskom nauku

42 Pogledati šire u knjizi Urlicha Becka 'Svjetsko rizično društvo', Novi Sad, Podgorica, UK, 2011. godina počev od stranice 292 nadalje

43 Vidjeti šire u Jean Baudrillard, Pakt lucidnosti ili Inteligencija zla, Zagreb, 2009. počev od strane 25 
Kakve ovo veze ima s religijom? Evo barem kakve veze ima s islamom? Gotovo na dvije trećine prostora pogoleme knjige, Kur'anu, od preko 600 stranica je govor o sihru, magiji, zavođenju kao ponajvažnijoj temi. Posebno u pričama o Mojsiju, Musau, poslaniku Židovima. Poslanici pa i sam Mojsije, Musa as. koji je mucao, poslan je s bratom Aronom, Harunom as. oslabljenim Židovima, pokorenim sihrom, magijom i manipulacijom da se suoče sa sihrom, magijom, iluzijom te poučeni kako da je savladaju. Kako da ukažu na štetnost i opakost magije. Kako dakle da odgovore u svom trenu postojanja na zavođenje, na manipulaciju i na prevaru. Kako da spoznaju Istinu?? Savremena magija je u tehnopolu, u tehnologiji i ekraničkoj kao simulakrumskoj kulturi, a ona se čini svemoćnom. Bar zasad! U našem dobu i našemu iskustvu.

Oduvijek i trajno, kao i danas uostalom, mnogo je onih koje krasi inteligencija zla kako ju definira Baudrillard, koja odlično manipulira, zavodi i stvara iluzije. I u svakom vremenu zadaća mislećih, odabranih i duhovno snažnih je kako odgovoritina sihr, magiju, manipulaciju i kako otkriti i sačuvati istinu?! Obično to nisu formalni religijski lideri! Baudrillard veli da je to jako teško moguće jer od hiljadu ljudi tek jedan, dva imaju vremena i strpljenja da o ovome misle. A tek jedan od nekoliko hiljada ima u sebi duha. Ovako isto je govoroi i pisao jedan sarajevski šejh, mesnevihan kazivač velikoga epa 'Mesnevija' Dželaludina Rumija hazreti Mevlanata, hadži Hafiz Halid Hadžimulić u svojim dnevničkim sjećanjima. Samo je jedan od hiljadu na Pravom Putu Spozanje.

On sugerira kako umjetna inteligencija, vrh obmane jest tehničko rješenje za mišljenje svijeta koje je ojalovilo, koje nas/svijet misli kao inteligencija zla. ${ }^{44}$ Da, postoji ta inteligencija zla, jer ne možemo osloboditi dobro a da ne oslobodimo zlo. Nas čeka svijet kao savršena kopija za koju čak nećemo znati da jest kopija. Šta dakle postaje izvornik kada kopija prestaje biti kopija? ${ }^{45}$ Ovo vrijeme Integralne Stvarnosti - vještačkog svijeta kao kopije danas miješa sve, 'sve što smo s teškom mukom razdvojili, seksualizirali, transcendirali, sublimirali, metamorfomizirali kroz odmak, sve se to danas neprestano miješa...riječ je zapravo o beskrajnom redukcionizmu, neviđenom revizionizmu'.46 Otrcanost slike se pridružuje otrcanosti života, i u realitijima i počinje Integralna vidljivost kad vidimo da se u svemu danom pogledu, i nema šta više za vidjeti. 'Postati slikom znači - ne sačuvati nikakvu tajnu'.

Ima li mjesta i za svijet i za njegova dvojnika? Nema. Dvojnika treba potkopati. Vratiti lijepo lice pjesnika Imrana na vidno mjesto. Polahko, sitnim lagahnim koracima rasplitati sve čvor po čvor, sve saplitaljku po saplitaljku...Početi nanovo ko da je tek svijet stvoren, čist od mraka I inteligencije zla, I svom biću, u politeji, u ekonomiji, u harmoniji, u mjeri...Čini se da je to moguće kroz povratak detalju, fragmentu, nijansi, početku, iskonu, ljepoti zore I modrini povečerja, pravdi, ljepoti, ranoj utihloj duhovnosti, tihovanju i mirovanju, halki, u krugu, u zajednici istomišljenika i sadisajnika, primičući se originalu, bisernom zrnu u dubini mutne školjke, dragulju ispod debelih naslaga kamena i mahovine, u rijeci života koju svako rano jutro prije sabaha, ili cika zore veliki dostavljač istina, Džebrail, Džibril, Gabrijel posjeti i porine se u nju kako bi sa sedamdeset hiljada krilaca i

44 Baudrillard, Jean, Inteligencija zla ili Pakt lucidnsoti, Zagreb 2006. strana 46

45 Ibidem, strana 60

46 Ibidem, strana 68,69 
krila raspršio te divne milosne kapi živog života i njima spajao nebeski svod i zemlju, umornu od toliko prljavštine po njoj. Zemlju to najstrpljivije stvorenje što ga je ruka Božija ikada stvorila. ${ }^{47}$

Zašto o ovome šute religije i ljudi religije? Ako ne znaju, dužni su sve naučiti i prenijeti te darove znanje. Sve u velikim iskonskim knjigama ima zapisano. Ako znaju, nek pripovijedaju, o svih sedam stanica postojanja, jer 'Kada sljedbenici istine/Zašute pred Sljedbenicima laži, /ondaSljedbenici laži umisle/ Da su na istini.'

\section{Literatura:}

Agamben, Giorgio, (2006), 'Homo sacer', Suverena moć i goli život, Multimedijalni Institut, Zagreb

Alić, Sead, ( 2019), 'Masovna proizvodnja narcizma', Zagreb, 2019., Sveučilište Sjever I CFM Zagreb

Baudrillard, Jean, (2009),' Pakt lucidnosti ili inteligencija zla', Zagreb

Beck, Urlich,(2011), 'Svjetsko rozično društvo', Novi Sad, Podgorica, UK

Berđajev, Nikolaj, (2007), 'Filozofija slobodnog duha”, Dereta, Beograd

Briggs, A. Burke, P.( 2010), Social History of the Media: From Gutemberg to the Internet', Politiy Press, New York

Cvitković, Ivan, (2016),' Religija u zrcalu teorija”, CEIR, Sarajevo

Hadžimulić, hafiz Halid (2019), 'Dnevnici Iii III tom', Udruženje hadži Mujaga, Sarajevo

Helminski, Kabir, (2018), 'Živi prisutno', Sufijski put do budnog srca. TPO Fondacija, Sarajevo

Fejzić Čengić, Fahira (2018), 'Kao ribe u vodi’, Ka filozofiji medija ili kako opstati s medijima, Dobra knjiga, Sarajevo

Malouf, Amin, (2009),, 'Poremećenost sveta', Kada se naše civilizacije iscrpe, Laguna, Beograd

Paić, Žarko, (2018), ‘Tehnosfera I, II i II tom', Zagreb

Strobel Li, (2007), 'Zločin hrišćanstva, Da li je relgija opijum za narod, Metaphisyca, Beograd

http://www.buka.com/novosti/giorgio-agamben.razmišljanja.o.kugi

http://buka.com/novosti/procurili-prvi-podaci-o-se-najviše-obogatio-tokom-pandemij-

bogatasi-zaradili.434

http://corona-virus-prekretnica-za nadzor ljudi

47 Pogledati eksplikaciju u tekstu F. Fejzić Čengić 'Propitivanje religijskog bez dovoljno znanja', pripremljenom za Okrugli sto na temu ‘Religija, društvo, sekularizam' u Tuzli oktobra 2020. godine, koji čeka objavljivanje u Zborniku radova koji je u pripremi. 


\title{
Media Coverage of the Behaviour of Religious Hierarchies during the COVID-19 Period
}

\begin{abstract}
While the formal social isolation of the world and Sarajevo continues, while everything that happens around us, live and immersed, religious communities are also present. Like other cities touched and fulfilled by the three religions, which is Jerusalem first, Sarajevo emerges as the ervopic original. I follow speeches, appearances, public speeches or religious corona messages from three religious sources: Islam, Orthodoxy and Catholicism in this City. How much is similar, so much is different, how soothing is so stressful, how beneficial is so harmful.

What will happen in the end or ends? Who knows? Ah no one knows, fragile knowledge, said Antun Branko Simic, our great poet...
\end{abstract}

Key words: pandemic, religion, control, homo sacer.

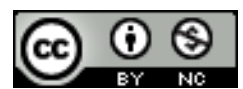

This journal is open access and this work is licensed under a Creative Commons Attribution-NonCommercial 4.0 International License. 